\title{
IMPLEMENTASI MANAJEMEN MUTU TERPADU PENDIDIKAN DI MTS NEGERI 6 BANJAR KECAMATAN MARTAPURA KABUPATEN BANJAR
}

\author{
${ }^{1}$ Mustika Damai Yanti, ${ }^{2}$ Zahra'unnisa Aulia \\ ${ }^{1}$ UIN Raden Intan Lampung \\ ${ }^{2}$ UIN Antasari Banjarmasin
}

Email: mustikadamai23@gmail.com

\begin{abstract}
ABSTRACK
The background of the problem in this study are 1) The high level ofpublic trust as evidenced by year after year MTs Negeri 6 Banjar is always in demand by the people of Banjar Regency. 2) there are programs excellence that supports the learning process. 3) always improving performance the achievements of MTs Negeri 6 Banjar from year to year. This Researcheraims to describe the implementation of integrated quality management in educationat MTs Negeri 6 Banjar on customer focus, total engagement, measurement, commitment, and continuous improvement. This research uses the theory of Jerome S. Arcaro. This study uses a descriptive qualitative approach. Data collection is done by conducting interviews, observations, and documentation. Analysis of the data used in this study was carried out by reduce the data, after that it is presented in the form of a description, and verified by conclusion.
\end{abstract}

\begin{abstract}
ABSTRAK
Latar belakang masalah dalam penelitian ini adalah 1) Tingginya tingkat kepercayaan masyarakat yang dibuktikan dengan dari tahun ke tahun MTs Negeri 6 Banjar selalu diminati oleh Masyarakat Kabupaten Banjar. 2) adanya program-program unggulan yang mendukung proses pembelajaran. 3) selalu meningkatnya prestasi-prestasi yang diraih MTs Negeri 6 Banjar dari tahun ketahun. Penelitain ini bertujuan untuk mendeskripsikan implementasi manajemen mutu terpadu pendidikan di MTs Negeri 6 Banjar pada fokus pada pelanggan, keterlibatan total, pengukuran, komitmen, dan perbaikan berkelanjutan. Penelitian ini menggunakan teori Jerome S. Arcaro. Penelitian ini menggunakan pendekatan kualitatif deskriptif. Pengumpulan data dilakukan dengan mengadakan wawancara, observasi, dan dokumentasi. Analisa data yang digunakan dalam penelitian ini dilakukan dengan mereduksi data, setelah itu disajikan dalam bentuk deskripsi, dan diverifikasi dengan penarikan kesimpulan.
\end{abstract}

Keyword: Manjemen Mutu Terpadu, Stakeholders, Pengukuran, Komitmen.

\section{PENDAHULUAN}

a. Implementasi

Secara sederhana implementasi bisa diartikan pelaksanaan atau penerapan. Kata "penerapan" menurut kamus besar bahasa Indonesia adalah "perbuatan menerapkan". Sedangkan menurut E.Mulyasa implementasi merupakan "suatu tindakan praktis sehingga memberikan dampak, baik perubahan pengetahuan, keterampilan maupun sikap"1.Implementasi yang penulis maksud dalam penulisan judul skripsi ini adalah "Penerapan Manajemen Mutu Terpadu Pendidikan di MTs Negeri 6 Banjar".

\section{b. Manajemen Mutu Terpadu Pendidikan (MMTP)}

Mutu adalah sebuah proses terstruktur untuk memperbaiki keluaran yang dihasilkan ${ }^{2}$, Sedangkan Terpadu atau Total berarti setiap orang, hal, aspek terlibat dan berpasrtisipasi

\footnotetext{
${ }^{1}$ E. Mulyasa, Kurikulum Tingkat Satuan Pendidikan kemandirian Guru dan Kepala Sekolah (Jakarta: Bumi Aksara, 2013), h. 178.

${ }^{2}$ Jerome S. Arcaro, Pendidikan Berbasis Mutu (Yogyakarta :Pustataka Pelajar, 2015), h. 75
} 
dalam organisasi ${ }^{3}$. Adapun pendidikan adalah usaha sadar dan terencana untuk mewujudkan suasana belajar dan proses pembelajaran agar peserta didik secara aktif mengembangkan potensi dirinya untuk memiliki kekuatan spiritual keagamaan, pengendalian diri, kepribadian, kecerdasan, akhlak mulia, serta keterampilan yang diperlukan dirinya, masyarakat, bangsa, dan negara. ${ }^{4}$

Jadi yang dimaksud manajemen mutu terpadu pendidikan (Total Quality Management) adalah suatu pendekatan yang memberikan perubahan didalam lembaga pendidikan dengan meningkatkan kualitas yang ada didalamnya melalui perbaikan terusmenerus untuk mencapai tujuan dengan melibatkan seluruh anggota organisasi.

\section{c. MTs Negeri 6 Banjar}

MTs Negeri 6 Banjar adalah adalah salah satu lembaga pendidikan yang terletak di Komplek Pp Darussalam, Jl. Tanjung Rema, Kecamatan Martapura, Kabupatn Banjar, Kalimantan Selatan, tempat dimana penulis melakukan penelitian. Berdasarkan penjelasan di atas maka maksud dari judul skripsi ini adalah untuk mengetahui bagaimana implementasi manajemen mutu terpadu pendidikan di MTs Negeri 6 Banjar 2 Kecamatan Martapura, Kabupatn Banjar.

Pendidikan berfungsi mengembangkan kemampuan, dan membentuk watak serta peradaban bangsa yang bermartabat dalam rangka mencerdaskan kehidupan bangsa, bertujuan untuk berkembangnya potensi peserta didik agar menjadi manusia yang beriman, dan bertakwa kepada Tuhan Yang Maha Esa, berakhlak mulia, sehat, berilmu, cakap, kreatif, mandiri, dan menjadi warga Negara yang demokratis serta bertanggung jawab ${ }^{5}$.

Pendidikan merupakan upaya yang dapat mempercepat pengembangan potensi manusia untuk dapat mengemban tugas yang dibebankan padanya, karena sejatinya tidak ada satupun mahluk yang dapat dididik, dan mendidik kecuali manusia.

Pendidikan dapat mempengaruhi perkembangan fisik, moral, emosioanal, mental, serta keimanan dan ketakwaan seseorang. ${ }^{6}$

Kualitas sumberdaya manusia dalam suatu negara sangat erat kaitannya dengan pendidikan yang ada didalamnya. Dengan adanya pendidikan disuatu Negara akan memberikan banyak manfaat baik dalam segi sosial maupun bagi individu didalamnya, yang menjadikan bangsa serta warganya bermartabat dan menjadikan sumberdaya manusianya menjadi individu yang memiliki derajat.

Untuk mencapai tujuan pendidikan yang berkualitas, dibutuhkan manajemen pendidikan yang dapat mengarahkan sumber daya pendidikan. manajemen pendidikan adalah proses manajemen dalam pelaksanaan tugas pendidikan dengan memanfaatkan segala sumber secara efisien untuk mencapai tujuan secara efektif. ${ }^{7}$ Tujuan sangatlah penting untuk meraih standar, standar yang ditetapkan biasanya berasal dari pelanggan baik internal, ataupun eksternal, standar dari pelanggan dapat menghasilkan mutu tertentu yang harus diraih agar mampu memuaskan pihak pelanggan tersebut.

Mutu suatu layanan tentu menjadi tujuan, karena hal ini mempengaruhi satu organisasi dibandingkan organisasi lain yang pada akhirnya menjadi daya saing bagi organisasi tersebut, begitupun halnya dalam lembaga pendidikan. guna mencapai kepuasan pelanggan suatu lembaga atau organisasi harus mencari pola manajemen yang tepat, salah satu bentuk manajemen yang berhasil dimanfaatkan dalam dunia industri dan bisa diadaptasi

\footnotetext{
${ }^{3}$ Umi Hanik, Implementasi Total Quality Management Dalam Peningkatan Kualitas Pendidikan (Semarang: RaSail Media Grup, 2011), h. 6-8

${ }^{4}$ UU RI No 20 Th. 2003, Sistem Pendidikan Nasional (Jakarta: Sinar Grafika, 2014), h.3.

${ }^{5}$ UU RI No 20 Th. 2003, Sistem Pendidikan Nasional ... . ., h. 7.

${ }^{6}$ Ubin Syaefudin S, Perencanaan Pendidikan (Bandung: PT Remaja Rosdakarya), h. 6

${ }^{7}$ Yasmina Alqur'an Terjemah dan Tajwid (Bandung: Sygma Creative Media Corp, 2014), h. 543.
} 
dalam dunia pendidikan adalah TQM ( Total Quality Management), TQM merupakan suatu pendekatan dalam menjalankan usaha yang mencoba untuk memaksimumkan daya saing organisasi melalui perbaikan terus-menerus atas produk, jasa, tenaga kerja, serta lingkungannya. ${ }^{8}$

Begitupun dalam dunia pendidikan, manajemen mutu terpadu pendidikan (Total Quality Manajemen in Education) menjadi sebuah pilihan untuk mencapai mutu terbaik. Manajemen mutu terpadu pendidikan merupakan salah satu paradigma dalam menjalankan bisnis bidang pendidikan yang berupaya memaksimalkan daya saing sekolah melalui perbaikan-perbaikan secara berkesinambungan atas kualitas, produk, jasa, manusia, proses dan lingkungan sekolah.

Adapun strategi yang dikembangkan dalam penggunaan manajemen mutu terpadu dalam dunia pendidikan adalah, institusi pendidikan menjadikan dirinya sebagai institusi jasa, yakni institusi yang memberikan pelayanan sesuai dengan apa yang diinginkan oleh pelanggan . jasa tau pelayanan yang diinginkan pelanggan tentu saja sesuatu yang bermutu dan memberikan kepuasan kepada mereka. Maka pada saat itulah dibutuhkan suatu sistem manajemen yang mempu memberdayakan istitusi pendidikan agar lebih bermutu.

Untuk menciptakan sebuah lembaga pendidikan yang bermutu sebagaimana diharapkan masyarakat, bukan hanya menjadi tanggung jawab sekolah, tetapi menjadi tanggung jawab semua pihak termasuk didalamnya orang tua dan pelanggan internal maupun eksternal. Jerome S. Arcaro menyampaikan bahwa terdapat lima prinsip sekolah bermutu yaitu Fokus pada pelanggan, Keterlibatan total, Pengukuran, komitmen, serta Perbaikan berkelanjutan. ${ }^{9}$

Dilihat dari kelima prinsip menurut Jerome misi utama dari manajemen mutu terpadu pendidikan ini adalah fokus kepada pelanggan serta memenuhi kepuasan pelanggan. Tanpa mutu yang sesuai dengan keinginan pelanggan serta kebutuhannya, sekolah akan kehilangan pelanggannya karena suatu pendidikan dikatakan bermutu apabila antara pelanggan internal dan eksternal telah terjalin kepuasan atas jasa yang diberikan; ${ }^{10}$ Kedua adalah keterlibatan total jadi manajemen mutu terpadu menuntut Semua pihak bertanggung jawab untuk memecahkan masalah, serta menuntut semua tim memberi kontribusi bagi transformasi mutu; Ketiga adalah pengukuran yaitu pengumpulan data untuk mengukur sejauh mana perencanaan telah dilaksanakan, serta melakukan evaluasi atas rencana yang telah dilaksanakan; Selanjutnya yang keempat adalah komitmen semua stakeholders memiliki komiten jangka panjang dalam mewujudkan visi dan misi serta dapat melakukan perubahan budaya agar penerapan manajemen mutu terpadu berjalan sukses; Terakhir adalah perbaikan berkelanjutan semua anggota secara konstan mencari cara untuk memeperbaiki setiap segala proses pendidikan seperti mengikuti workshop maupun pelatihan. ${ }^{11}$

Tingginya minat masyarakat yang masih berlomba-lomba untuk memasukkan anaknya di MTs Negeri 6 Banjar, serta prestasi-prestasi yang diraih membuat penulis tertarik untuk mengadakan penelitian disana, adapun hasil pra-penelitian penulis ketika mengadakan observasi di Madrasah Tsanawiyah Negeri 6 Banjar, menunjukan bahwa pelaksanaan manajemen mutu terpadu di Madrasah Tsanawiyah Negeri 6 Banjar sudah Berjalan dengan baik namun memang masih ada beberapa kendala yang dihadapi. Adapun keberhasilan manajemen mutu terpadu di MTs Negeri 6 Banjar ditandai dengan adanya lingkungan madrasah yang kondusif, islami, serta menyanangkan; adanya keterlibatan guru, staf, serta

\footnotetext{
${ }^{8}$ Fandy Tjiptono, Anastasia Diana, Total Quality Management (Yogyakarta: Andi Offset, 2003), h.4.

${ }^{9}$ Jerome S. Arcaro, Pendidikan Berbasis Mutu. . . . , h.43-44.

${ }^{10}$ Husaini Usman, MANAJEMEN Teori, Praktik, dan Riset Pendidikan (Jakarta: Bumi Aksara, 2014), h.. 604.

${ }^{11}$ Jerome S. Arcaro, Pendidikan Berbasis Mutu . . . . , h. 38-42
} 
wali murid dalam pengambilan keputusan, pengadaan sarana dan prasarana; serta adanya pembagian tugas dan penanggung jawab dengan mengikut sertakan personil yang ada, dan memberikan pembinaan dan pengarahan yang baik dalam pelatihan dan pengembangan baik secara langsung maupun tidak langsung; tidak hanya itu MTs Negeri 6 Banjar juga selalu mengadakan rapat tahunan tentang sosialisasi tata tertib dan hal lainnya kepada wali murid, serta mengadakan rapat komite sekolah.

\section{TINJAUAN PUSTAKA}

\section{A. Manajemen Mutu Terpadu Pendidikan}

1. Pengertian Manajemen Mutu Terpadu

a. Manajemen

Manajemen berasal dari bahasa latin Manus, yang berarti tangan, dan Ageree yang berarti melakukan. Kata-kata itu digabung menjadi Managere yang artinya menangani. Managere diterjemahkan ke Bahasa inggris to manage (kata kerja), management (kata benda) dan manager untuk orang yang melakukannya. Management diterjemahkan kedalam bahasa Indonesia menjadi manajemen yang berarti pengelolaan. ${ }^{12}$

Menurut Mustafa D. Manajemen adalah penggunaan sumber daya manusia dengan efektif dan efisien, material, keuangan, informasi, gagasan, serta waktu yang efisien melalui proses administrasi planning, organizing, actuating, control untuk mencapai tujuan.

Definisi menurut para ahli, seperti yang didefinisikan Robbins dalam Engkoswara manajemen adalah suatu proses untuk membuat aktivitas terselesaikan secara efisien dan efektif dengan melalui orang lain. Sedangkan menurut George R. Terry, Manajemen adalah suatu proses yang jelas terdiri dari tindakan-tindakan perencanaan, pengorganisasian, penggerakan, dan pengendalian yang dilaksanakan untuk menentukan serta melaksanakan sasaran atau tujuan yang telah ditentukan dengan menggunakan sumberdaya dan sumberdaya lainnya. Sejalan dengan dua pengertian di atas Sudjana mendefinisikan manajemen sebagai rangkaian berbagai kegiatan yang wajar yang dilakukan seseorang berdasarkan norma-norma yang telah ditetapkan dan dalam pelaksanaannya memiliki hubungan dan saling keterkaitan dengan lainnya. ${ }^{13}$

Setiap ahli memberi pandangan yang berbeda tentang batasan serta pengertian manajemen, namun dapat penulis simpulkan bahwa definisi manajemen kebanyakan menyatakan bahwa manajemen merupakan suatu proses mendayagunakan individu, dan sumberlainnya untuk mencapai tujuan suatu organisasi secara efektif dan efisien.

b. Mutu

Mutu memiliki pengertian yang bervariasi sebagai suatu konsep mutu sama halnya dengan sifat baik, cantik, dan benar. seperti yang dinyatakan Nomi Preffer dan Anna Coote dalam Edward Sallis, "Mutu merupakan konsep yang licin" mutu mengimplikasikan hal-hal yang berbeda pada masing-masing individu. ${ }^{14}$

Banyak pakar dan organisasi yang mencoba mendefinisikan mutu berdasarkan sudut pandangnya masing-masing. Juran dalam Abdul Hadis mendefinisikan Mutu sebagai kecocokan penggunaan produk untuk kebutuhan pelanggan (fitness for use), kecocokan pengguna produk tersebut didasarkan atas lima ciri utama teknologi yaitu kekuatan; psikologis yaitu cita rasa; waktu yaitu kehandalan; Kontraktual yaitu jaminan; etika yaitu sopan santun. Kecocokan penggunaan produk tersebut memiliki dua aspek utama yang pertama memenuhi tuntutan kostumer dan yang kedua adalah tidak memiliki kelemahan.

\footnotetext{
${ }^{12}$ Husaini Usman, MANAJEMEN Teori, Praktik, dan Riset Pendidikan . . . . . , h. 5

${ }^{13}$ Engkoswara, Aan Komariah, Administrasi Pendidikan. . . . . , h. 86-87

${ }^{14}$ Edward Sallis, Total Quality Management In Education (Yogyakarta: IRCiSoD, 2012), h.50
} 
Jika kedua hal ini telah dimiliki oleh sebuah perusahaan atau lembaga pendidikan, lembaga tersebut akan tetap eksis dan solid dalam era global dengan muatan kompetisi. ${ }^{15}$

Menurut Crosby Mutu adalah kesesuaian dengan yang disyaratkan atau distandarkan "quality is conformance to customer requirement"

Deming mengemukakan bahwa mutu adalah cocok dengan persyaratan dan dalam jangka panjang tanpa cacat, sedangkan Goetsch dan Davis dalam Engkoswara mengatakan bahwa Mutu adalah suatu kondisi yang dinamis yang berhubungan dengan produk, jasa, manusia, proses, dan lingkungan yang memenuhi atau melebihi harapan. ${ }^{16}$

Melihat definisi-definisi di atas dapat ditarik kesimpulan bahwa Mutu adalah kondisi dinamis yang berhubungan dengan produk, jasa, manusia proses, dan lingkungan yang memenuhi atau melebihi harapan pelanggan. Adapun dalam bidang pendiddikan mutu berkenaan dengan, proses, lingkungan sekolah, serta hasil pendidikan, yang dapat memenuhi harapan masyarakat dan dunia kerja.

Dapat disimpulkan bahwa mutu pendidikan bersifat relatif, karena tidak semua orang memiliki ukuran yang sama persis, namun demikian jika mengacu pada pengertian mutu secara umum dapat dinyatakan bahwa, pendidikan yang bermutu adalah pendidikan yang komponennya memiliki persyaratan dan ketentuan yang diinginkan oleh pelanggan serta menimbulkan kepuasan. Mutu pendidikan adalah baik, jika pendidikan tersebut dapat menyajikan jasa yang sesuai dengan kebutuhan para pelanggannya.

Standar mutu pendidikan dapat dirujuk dari standar nasioanal pendidikan yang tertera didalam Undang-Undang RI No 20 Tahun 2003 tentang Sistem pendidikan Nasioanal Bab IX Pasal 35 Ayat 1 yang berbunyi : "Standar nasional pendidikan terdiri atas standar isi, proses, kompetensi lulusan, tenaga kependidikan, sarana dan prasarana, pengelolaan, pembiayaan, dan penilaian pendidikan yang harus ditingkatkan secara berencana dan berkala". ${ }^{17}$

\section{c. Manajemen Mutu Terpadu (Total Quality Management)}

Total Quality Management atau Manajemen Mutu Terpadu Pendidikan sangat popular dilingkungan organisasi profit, khususnya diberbagai badan usaha atau perusahaan serta industri, yang memang telah terbukti keberhasilannya dalam mempertahankan dan mengembangkan eksistensinya masing-masing dalam kondisi yang sangat kompetitif. dalam Handbook Of Total Quality Management menjelaskan bahwa : "Total quality management A company-wide application of quality that requires the involvement and participation of everyone in the organization and a strong support and commitment from top management.". ${ }^{18}$

kutipan diatas menjelaskan bahwa penerapan manajemen mutu diseluruh organisasi maupun perusahaan memerlukan keterlibatan dan partisipasi seluruh individu didalam organisasi serta dukungan dan komitmen yang kuat dari manager puncak.

Kata Total berarti setiap orang, hal, aspek terlibat dan berpastisipasi dalam organisasi, Quality berarti memenuhi kebutuhan pelanggan, sedangkan Management berarti usaha untuk mencapai tujuan bersama. ${ }^{19}$

Seperti halnya Mutu definisi manajemen mutu terpadu pun bermacam-macam menurut Santosa dalam Fandy Tdijptono Manajemen Mutu Terpadu adalah sistem

\footnotetext{
${ }^{15}$ Abdul Hadis, Nurhayati, Manajemen Mutu Pendidikan (Bandung: Alfabeta, 2014), h. 84-85

${ }^{16}$ F. Sarhan, Idaaratu Al-Juudah Al-Syaamilah (El-Sherif Mass, 2011), h. 13

${ }^{17}$ UU RI No 20 Th. 2003, Sistem Pendidikan Nasional. . . . . , h.23-24

${ }^{18}$ Christian N., Handbook of Total Quality Management (New York USA: Springer Science and

${ }^{19}$ Umi Hanik, Implementasi Total Quality Management Dalam Peningkatan Kualitas Pendidikan. . . . .
} Business, 1998), h. xxxii , h. $6-8$ 
manajemen yang mengangkat kualitas sebagai strategi usaha dan berorientasi pada kepuasan pelanggan. ${ }^{20}$

Menurut Nawawi manajemen mutu terpadu adalah manajemen fungsional dengan pendekatan secara terus menerus difokuskan pada peningkatan kualitas, agar produknya sesuai dengan standar kualitas masyarakat yang dilayani dalam pelaksanaan tugas pelayanan umum dan pembangunan masyarakat.

Sejalan dengan pengertian dua para ahli diatas maka Nasution mengemukakan Manajemen Mutu Terpadu adalah siste m manajemen yang mengangkat kualitas sebagai strategi usaha dan berorientasikan pada kepuasan pelanggan dengan melibatkan seluruh anggota organisasi. Manajemen mutu terpadu merupakan suatu pendekatan dalam menjalankan usaha yang mencoba memaksimalkan daya saing organisasi melalui perbaikan terus-menerus, atas produk, jasa, tenaga kerja, proses, serta lingkungannya. ${ }^{21}$

Manajemen mutu terpadu bukanlah seperangkat peraturan dan ketentuan yang kaku dan harus diikuti, melainkan seperangkat prosedur dan proses untuk memperbaiki kinerja dan meningkatkan mutu kerja. Adapun yang membedakan TQM dengan manajemen lainnya adalah berkenaan dengan perbaikan berkelanjutan yang ada didalamnya, yang dimaksud kualitas total dalam TQM bukan berarti perbaikan secara instan melainkan merubah cara melalukan sesuatu menjdi lebih baik secara-terus menerus secara konstan san selamanya. Hal tersebut sejalan dengan Gopal K. Kanji dalam bukunya Total Quality Management yang mengatakan bahwa:

"differentiates TQM from other management processes is the emphasis on continuous improvement. Total quality is not a quick fix, it is about changing the way things are done forever,"22

\section{Pengertian Manajemen Mutu Terpadu Pendidikan}

Menurut Husaini Usman manajemen mutu terpadu pendidikan adalah budaya peningkatan mutu pendidikan secara terus menerus, fokus pada pelanggan sekolah, demi kepuasan jangka panjangnya, dengan partisipasi warga sekolah, keluarga, masyarakat serta pemerintah. 23

Perbaikan terus-menerus oleh orang jepang disebut kaizen. Kaizen diterjemahkan sebagai perbaikan sedikit demi sedikit tetapi terus-menerus. Esensi kaizen adalah memperbaiki yang kecil-kecil terlebih dahulu namun sangat vital untuk mencapai keberhasilan. Dengan keberhasilan timbul rasa percaya diri untuk memperbaiki yang besarbesar. $^{24}$

Sedangkan misi utama manajemen mutu terpadu pendidikan adalah memenuhi kepuasan pelanggan. Menurut Peter semua organisasi yang ingi mempertahankan keberadaannya harus obsesi pada Mutu. Mutu harus sesuai dengan persyaratan keinginan pelanggan. Tanpa mutu yangs sesuai dengan keinginan pelanggannya, sekolah akan kehilangan pelanggannya, dan sekolah yang kehilangan pelanggannya akan tutup dan bubar.

Manajemen mutu terpadu (MMTP) menjadikan suatu gagasan sebagai sebuah filosofi perubahan terus menerus hanya dapat dicapai oleh dan melalui individu didalamnya. Adapun untuk mengembangkan budaya perbaikan terus-menerus prosesnya diawali dengan mengembangkan visi dan misi sekolah serta bagian didalamnya.tugas pertama kepala sekolah adalah memberikan kepercayaan kepada warga sekolahnya dan mendelegasikan

\footnotetext{
${ }^{20}$ Fandy Tjiptono, Anastasia Dian, Total Quality Management. . . . . , h.4.

${ }^{21}$ Umi Hanik, Implementasi Total Quality Management Dalam Peningkatan Kualitas Pendidikan. . . . .

${ }^{22}$ Gopal K. Kanji, Total Quality Management (Chapman and Hall in: 1995), h. 03

${ }^{23}$ Husaini Usman, MANAJEMEN Teori, Praktik, dan Riset Pendidikan. . . . . , h. 602.

${ }^{24}$ Ibid. h. 603
} , h. $8-9$ 
kewenangan pada level yang sesuai, agar stafnya turut bertanggung jawab terhadap peningkatan mutu. Jadi MMTP awalnya bersifat dari atas kebawah. Setelah bawahan menerimanya selanjutnya MMTP dilakukan oleh seluruh warga sekolah secara sinergi. Tugas terakhir kepala sekolah adalah "mengucapkan terimakasih" kepada semua pihak yang terlibat dalam penerapan MMTP.

Manfaat Manajemen mutu terpadu pendidikan banyak sekali baik bagi pelanggan, institusi, maupun staff. Adapun manfaat manajemen mutu terpadu bagi pelanggan adalah sedikit atau bahkan tidak memiliki masalah dengan produk atau layanan, pelanggan diperhatikan, kepuasan pelanggan terjamin. ${ }^{25}$

Manfaat manajemen mutu terpadu bagi Isntitusi adalah terhadap perubahan kualitas atau pelayanan, staff lebih termotivasi, produktivitas meningkat, biaya turun, produk cacat berkurang, permasalahan dapat diselesaikan dengan cepat. ${ }^{26}$

Manfaat manajemen mutu terpadu bagi para staff organisasi adalah adanya pemberdayaan, lebih terlatihnya kemampuan, dan lebih diakui serta dihargai. Manfaat lain dari implementasi manajemen mutu terpadu yang dapat dirasakan dimasa yang akan datang adalah, dapat membuat institusi sebagai Leader bukan hanya sekedar follower (pengikut), membantu terciptanya tim work, membuat istitusi lebih peka terhadap kebutuhan pelanggan, dan tetntunya dapat membuat istitusi siap dan lebih mudah beradaptasi pada perubahan. ${ }^{27}$

\section{B. Implementasi Manajemen Mutu Terpadu Pendidikan}

Dalam bukunnya Jerome S. Arcaro mengemukakan bahwa pada dasarnya sekolah bermutu memiliki 5 karakteristik yang diidentifikasikan seperti pilar mutu, pilar-pilar tersebut didasarkan pada keyakinan sekolah seperti kepercayaan, kerja sama, serta kepemimpinan. Mutu dalam sebuah lembaga pendidikan meminta adanya komitmen pada kepuasan kostumer serta komitmen untuk mencapai sebuah lingkungan yang memungkinkan staf dan siswa menjalankan pekerjaan sebaik-baiknya. ${ }^{28}$ Adapun 5 prinsip sekolah bermutu dalam Jerome S. Arcaro meliputi:

\section{Fokus pada Pelanggan (costumer)}

Dalam manajemen mutu terpadu pendidikan atau yang lebih dikenal dengan MMTP, konsep mengenai mutu dan pelanggan diperluas. Mutu tidak lagi hanya bermakna dengan kesesuaian dengan spesifikasi-spesifikasi tertentu, tetapi mutu tersebut ditentukan oleh pelanggan. Education

Seperti yang dikatakan Edward Sallis dalam bukunya Total Quality Management In "Organization who take quality seriously know that much of the secret of quality stems from listening to and responding sympathetically to the needs and wants of their customers and clients"

Edward Sallis menjelaskan bahwa organisasi yang memiliki kualitas yang baik didapatkan dengan banyak mendengarkan dan menanggapi kebutuhan serta keinginan pelanggan mereka secara baik dan simpatik. Begitupun dengan pendidikan, pendidikan adalah pelayanan jasa, sekolah harus memberikan pelayanan jasa sebaik-baiknya kepada pelanggannya.

Pelanggan sekolah meliputi pelanggan internal serta pelanggan eksternal. pelanggan dalam (Internal customer) yang pengelola institusi pendidikan itu sendiri seperti, manager, guru, staff, dan, dan yang kedua adalah pelanggan luar (External customer) yang meliputi, masyarakat, pemerintah, komite sekolah serta dunia industri. dalam arti lain sekolah

\footnotetext{
${ }^{25}$ Yundri Akhyar, Total Quality Management, Jurnal Potensia vol 13. Edisi 01 Januarijuni 2014, h. 10

${ }^{26}$ Ibid.

${ }^{27}$ Ibid. h. 11.

${ }^{28}$ Fandy Tjiptono, Anastasia Diana, Total Quality Management . . . . . , h. 14
} 
mempunyai pelanggan primer, sekunder, dan tertier. Pelanggan primer sekolah adalah siswa, pelanggan sekunder sekolah adalah orang tua, serta pelanggan tertier sekolah adalah pemerintah dan masyarakat.

Kebutuhan pelanggan diusahakan untuk dipuaskan dalam segala aspek, termasuk didalamanya harga, keamanan, ketepatan waktu, dan lembaga pendidikan dapat mengatasi keluhan permasalahan dengan baik. Oleh karena itu segala aktivitas pendidikan harus dikoordinasikan untuk memuaskan para pelanggan. adapun keberhasilan dari fokus pada pelanggan dalam bidang pendidikan dapat ditandai dengan:

a. Secara berkala mengadakan pertemuan dengan guru, staff, serta orangtua untuk mengetahui keinginan serta kebutuhan

b. Memenuhi harapan serta keinginan pelanggan

c. Memberikan kenyamanan dan mengatasi keluhan permasalahan dengan memuaskan.

d. Sarana dan pra-sarana yang dibangun memenuhi persyaratan dan berfungsi dengan baik.

\section{Keterlibatan total (Kerjasama Tim dan keterlibatan Stakeholders)}

Dalam suatu sekolah yang tergolong bertaraf internasional, setiap indiviu dipandang memiliki talenta dan kreativitas yang khas. Dengan demikian setiap individu merupakan sumberdaya organisasi yang paling bernilai, oleh karena itu setiap individu dalam sebuah organisasi diperlakukan dengan baik, dan diberi kesempatan untuk terlibat dan berpartisipasi dalam pengambilan keputusan. Tidak hanya itu, Kerjasama tim serta kemitraan dibina dengan baik antara warga sekolah maupun luar sekolah. Setiap orang harus berpartisipasi dalam transformasi mutu, mutu bukan hanya menjadi tanggung jawab dewan sekolah ataupun pengawas. Mutu merupakan tanggung jawab semua pihak. Mutu menuntut setiap orang memberi kontribusi bagi upaya mutu.

Rolf E. Rogers dalam bukunya Implementation of Total Quality Management mengatakan bahwa :

"teams get involved in problem detection as well as making the decisions necessary to solve the problems and improve production processes"

Rolf menjelaskan bahwa tim terlibat dalam deteksi masalah serta membuat keputusan untuk pemecahan masalah agar dapat meningkatkan proses produksi bersama. Adapun keberhasilan dari keterlibatan total dalam lingkup pendidikan dapat ditandai dengan:

a. Kerjasama tim serta kemitraan dibina dengan baik, antara warga sekolah meupun luar sekolah

b. Semua pihak pihak bertanggung jawab untuk memecahkan masalah, serta memberi kontribusi terhadap mutu

Adanya Hubungan saling ketergantungan merupakan strategi untuk meningkatkan kinerja tim dalam pencapaian tujuan. Guru dan staf sebagai pelanggan internal turut memberikan jasa kepada pelanggan eksternal. Hubungan internal yang kurang baik akan menghalangi perkembangan sebuah institusi sekolah dan pada akhirnya membuat pelanggan eksternal menderita. Salah satu tujuan manajemen mutu terpadu pendidikan adalah merubah sebuah institusi sekolah menjadi sebuah tim yang ikhlas tanpa konflik. Untuk meraih sebuah tujuan utama yaitu memuaskan seluruh pelanggan. Kerja tim yang efektif berprinsip TEAMWORK yaitu singkatan dari:
Together
: Bersama-sama
Empathy : Pandai merasakan perasaan orang lain
Asist $\quad$ : Saling membantu
Maturity : :Saling penuh kedewasaan
Wilingness : Saling penuh keikhlasan
Organization : Saling terarur
Respect : Saling menghormati
Kindness : Saling berbaik hati. 


\section{Pengukuran}

Sistem mutu selalu membutuhkan rangkaian umpan balik. Mekanisme umpan balik harus ada dalam sistem mutu. Dalam Manajemen mutu terpadu Mengumpulkan data bukan sekedar perasaan (feeling). Pengukuran berfungsi untuk untuk mengukur sejauh mana perencanaan telah dilaksanakan serta Mengadakan evaluasi secara berkala atas perencanaan yang telah dilaksanakan. Didalam pengukuran inipun menuntut manager puncak atau kepala sekolah melihat apakah tugas-tugas yang telah diberikan kepada staf serta guru-guru sudah dikerjakan sesuai dengan mestinya dan sesuai jadwal atau sebaliknya. , adapun keberhasilan proses pengukuran dalam suatu lembaga pendidikan dapat ditandai dengan:

a. Kepala madrasah menciptakan struktur organisai yang mengandung kontrol

b. Madrasah mengadakan evaluasi secara berkala untuk mengetahui kinerja guru dan staff agar kekeliruan dalam bekerja berkurang

c. Mekanisme kerja guru, staff dibuat dengan menjabarkan deskripsi tugas masing-masing, seperti tugas mingguan, bulanan serta harian.

\section{Komitmen}

Robbins dan Judge mendefinisikan komitmen sebagai suatu keadaan dimana seorang individu memihak organisasi serta tujuan-tujuan dan keinginannya untuk mempertahankan keanggotaannya dalam organisasi. Sedangkan Mathis dan Jackson mendefinisikan komitmen organisasi sebagai derajat dimana karyawan percaya dan mau menerima tujuan-tujuan organisasi dan tetap tinggal atau tidak meninggalkan organisasinya. Sejalan dengan kedua pendapat tersebut Richard M. Steers mendefinisikan komitmen organisasi sebagai rasa identifikasi (kepercayaan terhadap nilai- nilai organisasi), keterlibatan (ketersediaan untuk berusaha sebaik mungkin demi kepentingan organisasi), dan loyalitas ( ketersediaan untuk tetap menjadi anggota organisasi yang bersangkutan) yang dinyatakan seorang pegawai terhadap organisasinya.63 Menurut Minners, ada 4 faktor yang mempengaruhi komitmen seseorang diantaranya:

a. Faktor personal, misalnya usia, jenis kelamin, tingkat pendidikan, pengalaman kerja serta kepribadian.

b. Karakteristik pekerjaan, misalnya lingkup jabatan, tantangan dalam pekerjaan, tingkat kesulitan dalam pekerjaan

c. Karakteristik struktur, misalnya besar kecilnya organisasi, bentuk organisasi.

d. Pengalaman kerja, pengalaman kerja guru dan staff sangat berpengaruh terhadap tingkat komitmen.

Sama halnya dalam suatu organisasi, seluruh anggota yang ada dalam sekolah harus memiliki komitmen jangka panjang dalam melakukan perubahan budaya agar penerapan manajemen mutu terpadu berjalan sukses, serta dapat mewujudkan visi dan misi didalamnya karena setiap orang perlu mendukung upaya mutu. Mutu merupakan perubahan budaya yang menyebabkan organisasi mengubah cara kerjanya, guna meningkatkan produktivitas, Bila mereka tidak mempunyai komitmen maka proses transformasi mutu tidak dapat dimulai. adapun keberhasilan dari menjaga komitmen dalam suatu lembaga pendidikan dapat ditandai dengan:

1) adanya komitmen stakeholders mewujudkan visi dan misi madrasah

2) mematuhi peraturan yang ada didalam madrasah

3) memiliki komitmen jangka penjang untuk melakukan perubahan kearah yang lebih baik

\section{Perbaikan Berkelanjutan}

Suksesnya sebuah lembaga pendidikan harus disertai dengan proses yang sistematis dalam melaksanakan perbaikan secara berkesinambungan. Sekolah mesti melakukan sesuatu yang lebih baik untuk esok hari. Para professional pendidikan harus secara konstan menemukan cara untuk menangani masalah yang muncul, dan membuat perbaikan yang diperlukan. 
Adapun dalam buku total Quality Management The Key To Business Improvement mengemukakan bahwa:

"Improvement is a process that must never stop. Once targets are met, new ones are set, aiming for even higher levels of product, process, and service efficiency."

Kutipan tersebut menjelaskan bahwa perbaikan adalah proses yang tidak boleh berhenti. Selalu ada target baru setelah target-target terdahulu tercapai. Semua itu bertujuan untuk menjadikan produk, proses serta layanan menjadi lebih baik lagi. proses perbaikan berkelanjutan bergantung pada dua unsur yaitu:

a. Mempelajari proses, alat, dan keterampilan yang tepat.

b. Menerapkan keterampilan baru baru diberbagai kegiatan sekolah.

Proses perbaikan berkelanjutan dapat dilakukan berdasarkan siklus PDCA (Plan-DoCheck-Action) siklus ini merupakan siklus yang never ending dan berlaku pada semua kegiatan sekolah, misalnya penerimaan siswa baru. Secara obyektif yang paling pertama diperbaiki adalah budaya kerja dan disiplin dari pelaksana sekolah (guru, karyawan, dan kepala sekolah) semuanya harus memandang siswa sebagai "pelanggan" yang harus dilayani sebaik-baiknya. Pelaksanaan sekolah dituntut selalu bersemangat untuk maju, menambah kemampuan, dan keterampilannya, yang pada akhirnya akan meningkatkan kinerja mereka dihadapan siswa. Apabila semua pelaksanaan sekolah sudah mempunyai budaya kerja, dan disiplin yang tinggi maka implementasi manajemen mutu terpadu pendidikan dapat secara nyata berjalan dan akan menjadikan sekolah semakin maju, memiliki brand image, yang semakin tinggi dan pada akhirnya dapat menciptakan pemimpin-pemimpin berkualitas.

\section{Penelitian yang Relaven}

Dari hasil penelitian yang dilakukan sebelumnya terdapat perbedaan dari segi objek, tempat, subjek, dan waktu penelitian. Adapun hasil penelitian sebelumnya yang berkaitan dengan implementasi manajemen mutu terpadu adalah sebagai berikut:

Jam Jami M. Syukri membahas tentang implementasi manajemen mutu terpadu di SD Negeri 3 Muara Pawan Kabupeten Ketapang Kalimantan Barat. Penelitian tersebut menunjukan bahwa ada beberapa temuan yang berhubungan dengan unsur pokok dari manajemen mutu terpadu di SD Negeri 3 Kecamatan Muara Pawan, yang menunjukan bahwa Implementasi manajemen mutu terpadu didalamnya sudah berjalan dengan baik. Adapun temuan-temuan tersebut berupa: 1) SD Negeri 3 Kecamatan Muara Pawan selalu melakukan perbaikan dengan meninjau kembali hasil-hasil dua tahun terakhir; 2) mengikut sertakan guru dan staff dalam pengembangan serta pelatihan; 3) berusaha menciptakan lingkungan yang kondusif dan menyenangkan; 4) serta memberikan penghargaan reward; 5) dan memberikan tugas dan informasi yang jelas kepada pendidik.

Adapun Era Yussmina, Murniati, Niswanto membahas tentang implementasi manajemen mutu terpadu dalam peningkatan kinerja sekolah pada SMK Negeri 1 Banda Aceh, penelitian ini bertujuan untuk mengetahui sejauh mana pentingnya penerapan manajemen mutu terpadu dalam meningkatkan kinerja sekolah. SMK Negeri 1 Banda Aceh sudah memiliki sertifikat ISO yang merupakan standar internasional yang diakui untuk sertifikasi manajemen mutu, serta adanya konsultan mutu yang selalu memberikan saran dan pengarahan dalam pengimplementasian manajemen mutu. Adapun bukti yang mendukung keberhasilan manajemen mutu terpadu adalah kecilnya angka pengangguran dari lulusan sekolah, dan adanya keikutsertaan komite sekolah, wali murid, serta adanya dukungan dinas pendidikan serta pemerintah kota.

Linda Wahyuning membahas tentang manajemen mutu terpadu di SMP 11 Ma"arif Bangsalsari. Implementasi manajemen mutu terpadu di SMP 11 Ma"arif Bangsalsari sudah berjalan cukup baik. Adapun penelitian tersebut bertujuan untuk mengetahui sejauh mana penerapan manajemen mutu terpadu di SMP 11 Ma"arif Bangsalsari dalam aspek komitmen yang dibangun didalamnya, perbaikan berkelanjutan, serta keterlibatan total dalam lembaga 


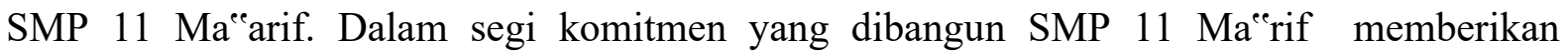
kompensasi agar para karyawan bekerja secara produktif, dalam segi perbaikan berkelanjutan di SMP $11 \mathrm{Ma}^{\text {ea } a r i f ~ d i l a k u k a n ~ d e n g a n ~ e v a l u a s i ~ k i n e r j a ~ r a p a t ~ s e k o l a h, ~ d a n ~}$ dalam segi keterlibatan total sekolah melibatkan masyarakat sekitar, komite, serta guru, staff, maupun siswa yang ada didalamnya.

\section{METODE}

\subsection{Teknik Pengumpulan Data}

Ada beberapa teknik yang digunakan dalam mengumpulkan data dalam penelitian ini, antara lain:

a. Metode Wawancara

Wawancara adalah sebuah dialog yang dilakukan oleh pewawancara untuk memperoleh informasi dari terwawancara. Menurut Sutrisno Hadi dalam Sugiyono mengemukakan bahwa anggapan yang perlu dipegang oleh peneliti dalam menggunakan metode interview dan juga kuesioner adalah sebagai berikut:

1) Bahwa subyek (responden) adalah orang yang paling tahu tentang dirinya sendiri

2) Bahwa apa yang ditanyakan oleh peneliti kepada subyek adalah benar dan dapat dipercaya

3)Bahwa interprestasi subyek tentang pertanyaan-pertanyaan yang diajukan peneliti kepadanya adalah sama dengan apa yang dimaksudkan oleh peneliti.

Berdasarkan pengertian di atas. Jelas bahwa metode interview (wawancara) merupakan salah satu alat untuk memperoleh informasi dengan jalan mengadakan komunikasi langsung antar dua orang atau lebih serta dilakukan secara lisan.Untuk memperoleh data yang valid dan akurat, penulis menggunakan jenis interview bebas terpimpin, yaitu suatu pelaksanaan interview yang dalam mengajukan pertanyaan yang disampaikan kepada responden di kemukakan secara bebas, tetapi isi pertanyaan yang diajukan pada pedoman yang telah ditetapkan.

Dalam penelitian ini penulis akan melakukan wawancara kepada: Kepala Sekolah, beberapa Guru/staff, Beberapa Siswa, serta dua orang Wali Murid

b. Observasi

Metode observasi diartikan sebagai pengamatan dan pencatatan secara sistematik terhadap gejala yang tampak pada objek penelitian. Observasi adalah alat pengumpulan data, pengamatan dan pencatatan yang sistematis terhadap fenomena-fenomena yang diteliti. Dalam arti luas, observasi tidak hanya terbatas pada pengamatan baik dilakukan secara langsung maupun tidak langsung.

c. Dokumentasi

Dokumentasi merupakan catatan peristiwa yang sudah berlalu. Dokumentasi bisa berbentuk tulisan, gambar, atau karya. Studi dokumentasi merupakan pelengkap dari penggunaan metode observasi dan wawancara.30 Metode dokumentasi diperlukan sebagai metode pendukung untuk mendapatkan data, karena dalam metode dokumentasi ini dapat diperoleh data-data historis dan dokumen lain yang relevan dengan penelitian ini. Motede dokumentasi adalah mencari data mengenai hal-hal atau variabel yang berupa catatan, transkip, buku, surat kabar, majalah, prasasti, notulen rapat, agendan dan sebagainya.

Jadi dokumentasi salah satu cara untuk menghimpun data mengenai hal-hal tertentu, melalui catatan-catatan, dokumen yang disusun oleh suatu instansi atau organisasi-organisasi tertentu.

\subsection{Sumber Data Penelitian}

Sumber data yang digunakan penelitian ini adalah data primer dan data sekunder:

a. Data Primer

Data primer adalah data dalam bentuk verbal atau kata-kata yang diucapkan secara lisan, gerak-gerik atau prilaku yang dilakukan oleh subyek yang dapat dipercaya, dalam hal ini adalah subyek penelitian (informa) yang berkenaan dengan yang diteliti.

Adapun data wawancara disini meliputi: Wawancara Kepala sekolah, beberapa Dewan Guru dan staff, beberapa Siswa, serta Wali Murid/Orang Tua dari Siswa MTs Negeri 6 Banjar.

b. Data Sekunder

Data sekunder adalah data yang diperoleh dari dokumen-dokumen grafis (tabel, catatan, notulen rapat, sms, dan lain-lain) foto-foto, film, rekaman video, benda-benda dan lain-lain yang dapat memperkaya data primer. Adapun data sekunder disini meliputi: dokumen grafis, serta foto. 


\subsection{Analisis Data}

Menurut Miles dan Huberman dalam Sugiyono, mengemukakan bahwa aktivitas dalam analisis data kualitatif dilakukan secara interaktif dan berlangsung terus menerus sampai tuntas, sehingga datanya sudah jenuh.

Sedangkan Menurut Sugiyono analisis data adalah proses mencari dan menyusun secara sistematis data yang diperoleh dari hasil wawancara, catatan lapangan, dan dokumentasi, dengan cara mengorganisasikan data ke dalam kategori, menjabarkan ke dalam unit-unit, melakukan sintesa, menyusun ke dalam pola, memilih mana yang penting dan yang akan dipelajari, dan membuat kesimpulan sehingga mudah difahami oleh diri sendiri maupun orang lain.

Adapun langkah-langkah yang diterapkan peneliti dalam menganalisa data yaitu reduksi data, paparan/penyajian data, dan verifikasi yang dilakukan selama dan sesuadah penelitian adalah:

a. Data Reduction (Reduksi Data)

Mereduksi data berarti merangkum, memilih hal-hal pokok, menfokuskan pada hal-hal yang penting, dicari tema dan polanya. Dengan demikian data yang telah direduksi akan memberikan gambaran yang lebih jelas, dan mempermudah peneliti untuk melakukan pengumpulan data selanjutnya, dan mencarinya bila diperlukan. Adapun data yang dianggap penting yaitu yang berkaitan dengan Implementasi Manajemen Mautu terpadu Pendidikan di MTs Negeri 6 Banjar.

b. Data Display (Penyajian Data)

Penyajian data yang baik merupakan cara yang pokok bagi analisis kualitatif yang valid. Setelah data direduksi, langkah selanjutnya adalah mendisplaykan data. Dalam penelitian kualitatif penyajian data bisa dilakukan dalam bentuk uraian singkat, bagan, hubungan antar kategori, flowchart, dan sejenisnya.

c. Conclusion Drawing/Verifikasi

Kesimpulan juga diverifikasi selama penelitian berlangsung. Secara sederhana, maknamakna yang muncul dari data yang muncul harus diuji kebenaran, kekuatan, dan kecocokannya, yakni yang merupakan validitasnya.

\subsection{Penguji Keabsahan Data}

Agar hasil penelitian dapat dipertanggung jawabkan maka dikembangkan tata cara untuk mempertanggung jawabkan keabsahan hasil penelitian, dengan memeriksa keabsahan datanya adapun cara untuk menguji keabsahan data dalam penelitian ini adalah menggunakan teknik triangulasi.

Triangulasi adalah teknik pemeriksaan keabsahan data yang memanfaatkan sesuatu yang lain, diluar data itu untuk keperluan pengecekan atau sebagai pembanding terhadap data itu. Denzin dalam Moeloeng, membedakan empat macam triangulasi diantaranya dengan memanfaatkan penggunaan sumber, metode, penyidik dan teori. :

a. Triangulasi dengan Sumber

Triangulasi dengan sumber yaitu untuk menguji kreadibilitas data dilakukan dengan cara mengecek data yang telah diperoleh melalui berbagai sumber dan Membandingkan keadaan serta perspektif seseorang dengan berbagai pendapat dan pandangan.dalam penelitian kualitatif untuk mencapai kepercayaan itu adalah:

1) Membandingkan data hasil pengamatan dengan data hasil wawancara.

2) Membandingkan keadaan dan perspektif seseorang dengan berbagai pendapat dan pandangan masyarakat dari berbagai kelas.

3) Membandingkan hasil wawancara dengan isi suatu dokumen yang berkaitan.

b. Triangulasi dengan Metode

Menurut Patton terdapat dua strategi, yaitu : (a) Pengecekan derajat kepercayaan penemuan hasil penelitian beberapa teknik pengumpulan data dan (b) Pengecekan derajat kepercayaan beberapa sumber data dengan metode yang sama.

c. Triangulasi penyidik

Triangulasi penyidik ialah dengan jalan memenafaatkan peneliti atau pengamat lainnya untuk keperluan pengecekan kembali derajat kepercayaan data. Cara lain adalah membandingkan hasil pekerjaan seorang analisis dengan analisis lainnya.

d. Triangulasi dengan teori

Menurut Lincoln dan Guba, berdasarkan anggapan bahwa fakta tidak dapat diperiksa derajat kepercayaannya dengan satu atau lebih teori. berarti cara terbaik untuk menghilangkaan perbedaan- 
perbedaan konstruksi kenyataan yang ada dalam konteks suatu studi, sewaktu mengumpulkan data tentang berbagai kenyataan dan hubungan dari berbagai pandangan.

Dengan demikian pada penelitian ini, uji kreadibilitas data hasil penelitian dilakukan dengan triangulasi sumber dan triangulasi metode, triangulasi sumber yaitu dengan cara membandingkan data hasil pengamatan dengan data hasil wawancara, dan membandingkan hasil wawancara dengan isi suatu dokumen yang berkaitan, dan triangulasi metode yaitu mengecek derajat kepercayaan penemuan hasil penelitian beberapa teknik pengumpulan data.

\section{HASIL PEMBAHASAN}

Menurut Husaini Usman manajemen mutu terpadu pendidikan adalah budaya peningkatan mutu pendidikan secara terus menerus, fokus pada pelanggan sekolah, demi kepuasan jangka panjangnya, dengan partisipasi warga sekolah, keluarga, masyarakat serta pemerintah.Misi utama Manajemen mutu terpadu pendidikan adalah memenuhi kepuasan pelanggan. Menurut Peter semua organisasi yang ingin mempertahankan keberadaannya harus obsesi pada Mutu. Mutu harus sesuai dengan persyaratan keinginan pelanggan. Tanpa mutu yangs sesuai dengan keinginan pelanggannya, sekolah akan kehilangan pelanggannya, dan sekolah yang kehilangan pelanggannya akan tutup dan bubar.

Dalam penelitian di MTs Negeri 6 Banjar ini penulis menggunakan teori dari Jerome S. Arcaro tentang 5 pilar mutu, Jerome menyampaikan bahwa terdapat lima prinsip sekolah bermutu yaitu Fokus pada pelanggan, Keterlibatan total, Pengukuran, komitmen, serta Perbaikan berkelanjutan.

\subsection{Fokus Pada Pelanggan}

Edward Sallis menjelaskan bahwa organisasi yang memiliki kualitas yang baik didapatkan dengan banyak mendengarkan dan menanggapi kebutuhan serta keinginan pelanggan mereka secara baik dan simpatik.

Kebutuhan pelanggan diusahakan untuk dipuaskan dalam segala aspek, termasuk didalamanya harga, keamanan, ketepatan waktu, dan lembaga pendidikan dapat mengatasi keluhan permasalahan dengan baik. Oleh karena itu segala aktivitas pendidikan harus dikoordinasikan untuk memuaskan para pelanggan. adapun keberhasilan dari fokus pada pelanggan dalam bidang pendidikan di MTs Negeri 6 Banjar Ditandai dengan:

a. Secara berkala mengadakan pertemuan dengan guru, staff, serta orangtua untuk mengetahui keinginan serta kebutuhan

Pada Fokus pada Pelanggan Internal MTs Negeri 6 Banjar selalu mengadakan rapat dewan Guru, dan Staff setiap bulannya, yang dipimpin langsung oleh kepala sekolah didalam rapat tersebut membahas program-program yang sedang dijalankan dan evaluasi sejauh mana keberhasilan dan kekurangan dari program-program tersebut, tidak hanya itu kesehjateraan Guru, serta kewajibannyapun diutamakan, adapun jika ada permasalahan dalam sekala kecil kepala Madrasah hanya mengadakan breaving dikantor dengan dihadiri koordinator masing- masing, dan koordinator tersebut yang menyampaikan kepada anggota- anggota yang bersangkutan.

Adapun untuk Fokus Pada Pelanggan Eksternal MTs Negeri 6 Banjar setiap awal tahun mengadakan pertemuan dengan Wali Murid khusunya Siswa baru untuk menyampaikan programprogram serta peraturan-peraturan yang ada didalam Madrasah yang dijembatani oleh Komite, didalam pertemuan itu Madrasah memberikan ruang bagi Wali Murid untuk membuka sesi Tanya Jawab yang berkaitan dengan MTs Negeri 6 Banjar baik dalam hal peraturan, program, atau kebijakan-kebijakan baru yang ada di MTs Negeri 6 Banjar, sehingga tidak adanya kesalahfahaman antara pihak Madrasah dengan Wali Murid atau Orang Tua.

b. Memenuhi harapan serta keinginan pelanggan

MTs Negeri 6 Banjar mempunyai program unggulan yang disebut bilingual class , Antusias masyarakat terhadap program inipun sangat tinggi, hal ini dibuktikan ketika pihak madrasah ingin menghapus dan menghilangkan program ini, namun Wali murid menolak, karena menurut mereka program tersebut sudah menjadi icon MTs Negeri 6 Banjar.

Program lain yang mendapatkan dukungan sangat baik dari Wali Murid selanjutnya yaitu program Tahfidz, program Tahfidz ini berfokus pada juz 30, 29 dan 28 dan setiap tahunnya 
diadakan wisuda tahfidz yang bekerjasama dengan Kanwil Kemenag Provinsi Kalimantan Selatan, dan juga Kanwil Kemenag Banjar.

MTs Negeri 6 Banjar juga sudah mendapatkan Akrditasi A, dengan adanya Akreditasi yang baik ini diharapkan dapat membantu siswa untuk diterima di SLTA favorit serta dibantu dengan adanaya pengembangan yang ada di MTs Negeri 6 Banjar sesuai minat dan bakat anak seperti sience club, social club, dan dalam bidang bahasa terdapat English and Arabic club. Semua itu dilakukan dalam rangka menjawab keinginan kedepan.

Para dewan Guru juga selalu memberikan motivasi kepada siswa untuk sampai kesekolah yang mereka pilih.

c. Memberikan kenyamanan dan mengatasi keluhan permasalahan dengan memuaskan.

MTs Negeri 6 Banjar dalam memberikan kenyamanan dan mengatasi keluhan maka pihak madrasah setiap awal tahunnya mengundang orang tua siswa untuk membicarakan kebijakan serta peraturan-peraturan yang ada di MTs Negeri 6 Banjar sehingga adanya keterbukaan, dan tidak terjadi kesalahfahaman antara pihak sekolah dengan Wali murid.

Adapun jika ada kritik dari Wali murid ataupun masyarakat pihak madrasah mendiskusikan bersama-sama apa yang jadi permasalahan, jika permasalahan tersebut tidak merugikan dan masih berjalan sesuai visi-misi maka harus diberikan penjelasan kepada Wali murid teresebut.

d. Sarana dan pra-sarana yang dibangun memenuhi persyaratan dan berfungsi dengan baik.

Jumlah siswa yang ada di MTs Negeri 6 Banjar memang belum diimbangi dengan jumlah Sarana dan prasarana yang ada, maka dari itu madrasah menggiatkan adanya Mushola baru karena sebelumnya siswa, Guru, dan staff melakukan sholat dzuhur berjamaah di Aula.

Banyak nya jumlah siswa tak sebanding dengan Toilet yang ada, karena di MTs Negeri 6 Banjar jumlah toilet siswa hanya ada 16 toilet jumlah yang cukup banyak namun masih belum cukup dengan dibandingkan jumlah Siswa yang ada.

Berdasarkan pemaparan diatas Implementasi Manajemen Mutu Terpadu fokus pada pelanggan di MTs Negeri 6 Banjar sudah berjalan cukup baik dengan selalu diadakannya pertemuan secara berkala dengan Guru dan Staff, serta Orang tua, MTs Negeri 6 Banjar telah ditunjang dengan akreditasi yang baik $\mathrm{A}$, dan didukung dengan program- program unggulan yaitu bilingual class, tahfidz, dan juga cub-club sesuai minat dan bakat siswa, dan jika ada kritik dari Wali murid Madrasah mendiskusikan bersama-sama apa yang jadi permasalahan, namun dalam hal sarana dan prasarana MTs Negeri 6 Banjar harus lebih diimbangi dengan jumlah siswa yang ada.

Penelitian yang dilakukan penulis selaras dengan penelitian yang dilakukan oleh Era Yussmina, Murniati, Niswanto yang membahas tentang Implementasi manajemen mutu terpadu dalam peningkatan kinerja sekolah pada SMK Negeri 1 Banda Aceh, hasil penelitian tersebut mengatakan bahwa adanya keikutsertaan komite sekolah, wali murid, serta adanya dukungan dinas pendidikan serta pemerintah kota.

\subsection{Keterlibatan total (Kerjasama Tim dan keterlibatan Stakeholders)}

Setiap individu merupakan sumberdaya organisasi yang paling bernilai, oleh karena itu setiap individu dalam sebuah organisasi diperlakukan dengan baik, dan diberi kesempatan untuk terlibat dan berpartisipasi dalam pengambilan keputusan. Tidak hanya itu, Kerjasama tim serta kemitraan dibina dengan baik antara warga sekolah maupun luar sekolah. mutu bukan hanya menjadi tanggung jawab dewan sekolah ataupun pengawas. Mutu merupakan tanggung jawab semua pihak. Mutu menuntut setiap orang memberi kontribusi bagi upaya mutu. Guru dan staf sebagai pelanggan internal turut memberikan jasa kepada pelanggan eksternal. Hubungan internal yang kurang baik akan menghalangi perkembangan sebuah institusi sekolah dan pada akhirnya membuat pelanggan eksternal kecewa. adapun keberhasilan dari keterlibatan total dalam bidang pendidikan di MTs Negeri 6 Banjar dapat ditandai dengan:

a. Kerjasama tim serta kemitraan dibina dengan baik, antara warga sekolah maupun luar sekolah

MTs Negeri 6 Banjar selalu mengadakan rapat 1 bulan sekali khusus Guru Bidang Study, disitulah Guru diberikan pembinaan dan pengarahan.MTs Negeri 6 Banjar juga dalam masingmasing bidang study mempunyai MGMP serta koordinator masing-masing, dan tentunya dibawah pembinaan kepala sekolah, khususnya pelajaran yang di UN kan, semua ada tim-tim untuk memajukan prestasi-prestasi yang diharapkan . 
Dari hasil wawancara dengan beberapa dewan Guru pun mengatakan kepala madrasah sudah cukup baik dalam kerjasama dengan seluruh Stakeholders kepala madrasah selalu berkomunikasi dengan dewan Guru dan Staff baik dalam waktu formal maupun jam istirahat, serta adanya keterbukaan, dan tidak hanya mengurusi pekerjaan yang ada diruangannya saja, begitupun jika ada peraturan, kegiatan, atau kebijakan baru kepala sekolah selalu mengkomunikasikan dengan dewan Guru dan Staff yang resminya dilakukan didalam rapat, adapun jika akan akan dilakukan lomba LCT, Olimpiade kepala sekolah selalu mengadakan rapat kecil dengan tim-tim nya dan melakukan breaving serta doa bersama.

Untuk pertemuan dengan Wali Murid dilakukan 1 tahun sekali dalam pertemuan tersebut membahas tentang program, kebijakan, serta tata tertib Madrasah, dan untuk wali kelas setiap Wali Kelas mempunyai identitas anak yang didalamnya terdapat nomor telfon orang tua.

Kerjasama antara Guru dan siswa diluar jam pelajaran pun dibina dengan baik seperti dalam pramuka, pelatih pramuka sendiri juga melibatkan beberapa dewan Guru.

b. Semua pihak pihak bertanggung jawab untuk memecahkan masalah, serta memberi kontribusi terhadap mutu.

Dewan Guru serta Staff MTs Negeri 6 Banjar mempunyai Tupoksi dan peranannya masingmasing, menurut kepala sekolah jika Guru dan Staff sudah menjalankannya dengan sebaikbaiknya sesuai job description dan bertanggung jawab terhadap kewajibannya, maka sudah ikut serta dalam satu pemecahan masalah dan memberikan kontribusinya terhadap Mutu, tidak hanya itu Guru dan Staff juga diikutsertakan dalam pengambilan keputusan, keputusan yang ditetapkan juga natinya tanpa memberatkan pihak manapun, karena keputusan itu akan dijalankan secara bersama-sama. Adapun jika permasalahan tersebut hanya dalam sekala kecil maka kepala sekolah hanya memanggil koordinator atau Waka yang bersangkutan untuk mengadakan Breaving dan koordinator yang nantinya akan menyampaikan kepada anggotanya.

Dalam memberikan kontribusinya terhadap Mutu, setiap guru di MTs Negeri 6 Banjar mempunyai cara yang berbeda-beda tetapi tetap satu tujuan, ada yang mengikuti seminar, workshop, dan pelatihan, ada juga yang memperbanyak literatur tentang berbagai metode pengajaran.

Berdasarkan penemuan diatas Implementasi Manajemen Mutu Terpadu Pendidikan Pada Keterlibatan total sudah berjalan dengan baik dengan adanya rapat guru bidang study setiap satu bulan sekali, MGMP, dan koordinator UN dibawah bimbingan kepala sekolah, serta dibinanya Kerjasama antara Guru dan siswa diluar jam pelajaran, kepala madrasah sudah cukup baik dalam bekerjasama dengan seluruh Stakeholders kepala madrasah selalu berkomunikasi dengan dewan Guru dan Staff baik dalam waktu formal maupun jam istirahat, dan guru serta staff pun mengerjakan tugas sesuia dengan Tupoksi dan job description masing- masing.

Penelitian yang dilakukan oleh penulis selaras dengan penelitian yang dilakukan oleh Linda Wahyuning membahas tentang Implementasi manajemen mutu terpadu di SMP $11 \mathrm{Ma}$ earif Bangsalsari. Adapun hasil dari penelitian tersebut mengatakan bahwa, dalam segi keterlibatan total sekolah melibatkan masyarakat sekitar, komite, serta guru, staff, maupun siswa yang ada didalamnya.

\subsection{Pengukuran}

Sistem mutu selalu membutuhkan rangkaian umpan balik. Mekanisme umpan balik harus ada dalam system mutu. Dalam Manajemen mutu terpadu Mengumpulkan data bukan sekedar perasaan (feeling). pengukuran berfungsi untuk untuk mengukur sejauh mana perencanaan telah dilaksanakan serta Mengadakan evaluasi secara berkala atas perencanaan yang telah dilaksanakan. Didalam pengukuran inipun menuntut manager puncak atau kepala sekolah melihat apakah tugas-tugas yang telah diberikan kepada staf serta guru-guru sudah dikerjakan sesuai dengan mestinya dan sesuai jadwal atau sebaliknya., adapun keberhasilan proses pengukuran di MTs Negeri 6 Banjar dapat ditandai dengan:

a. Kepala madrasah menciptakan struktur organisai yang mengandung control

MTs Negeri 6 Banjar mempunyai struktur organisasi yang mengandung kontrol, dibidang administrasi ada kepala TU, serta terbagi menjadi 4 waka: Waka kurikulum, humas, kesiswaan, dan Sarpras, dengan kepala madrasah sebagai penanggung jawab, semua itu dilakukan untuk mengontrol kinerja agar terkoordinasi dengan baik kepada pimpinan, tidak hanya itu 
ekstrakurikuler pun terdapat pembina dan pelatihnya masing-maisng, dan Kepala madrasah pun setiap pagi sebelum KBM dimulai yaitu ketika siswa sedang tadarus selalu mengontrol jalannya pembelajaran.

b. Madrasah mengadakan evaluasi secara berkala untuk mengetahui kinerja guru dan staff agar kekeliruan dalam bekerja berkurang

Evaluasi secara berkala di MTs Negeri 6 Banjar dilakukan dalam bentuk rapat evaluasi yang membahas tentang kendala-kendala dalam setiap program dan proses pembelajaran, dari rapat ini diharapkan Guru dan Staff dapat memberikan solusi terhadap kendala-kendala yang muncul. Evaluasi berkala juga dilakukan dalam bentuk supervisi yang dilakukan madrasah setiap 6 bulan sekali, adapun supervisor bersal dari guru senior yang ada di MTs Negeri 6 Banjar, dari situ bisa terlihat apa kekurangan dari Guru tersebut dan apa yang harus diperbaiki selanjutnya.

c. Mekanisme kerja guru, staff dibuat dengan menjabarkan deskripsi tugas masing-masing, seperti tugas mingguan, bulanan serta harian.

MTs Negeri 6 Banjar menjabarkan deskripsi tugas masing- masing dalam bentuk RPP, program tahunan, serta program semester, adapun untuk di TU adanya pembagian masalah kepegawaian, dan pembuatan laporan bulanan, sehingga seluruh kegiatan yang ada dapat tercover dengan jelas.

Berdasarkan pemaparan diatas Implementasi Manajemen Mutu Terpadu Pendidikan dalam hal pengukuran di MTs Negeri 6 Banjar sudah berjalan dengan baik dengan mempunyai struktur organisasi yang mengandung kontrol, Kepala madrasah pun selalu mengontrol jalannya pembelajaran, dan adanya rapat evaluasi, Evaluasi secara berkala juga dilakukan dalam bentuk supervisi, agar tercover dengan jelas MTs Negeri 6 Banjar menjabarkan deskripsi tugas masingmasing dalam bentuk RPP, program tahunan, serta program semester,

Penelitian yang dilakukan oleh penulis berbeda dengan penilitian yang dilakukan oleh Jam Jami M. Syukri yang membahas tentang Implementasi manajemen mutu terpadu di SD Negeri 3 Muara Pawan Kabupeten Ketapang Kalimantan Barat. Penelitian tersebut menunjukan bahwa Implementasi manajemen mutu terpadu didalamnya sudah berjalan dengan baik yaitu SD Negeri 3 Kecamatan Muara Pawan selalu melakukan evaluasi dan perbaikan dengan meninjau kembali hasil- hasil dua tahun terakhir, sedangkan temuan hasil penulis yaitu evaluasi secara berkala di MTs Negeri 6 Banjar dilakukan 1 bulan sekali dalam rapat evaluasi, evaluasi secara berkala juga dilakukan dalam bentuk supervisi kelas yang dilakukan 6 bulan sekali.

\subsection{Komitmen}

Robbins dan Judge mendefinisikan komitmen sebagai suatu keadaan dimana seorang individu memihak organisasi serta tujuan-tujuan dan keinginannya untuk mempertahankan keanggotaannya dalam organisasi.

Sama halnya dalam suatu organisasi, seluruh anggota yang ada dalam sekolah harus memiliki komitmen jangka panjang dalam melakukan perubahan budaya agar penerapan manajemen mutu terpadu berjalan sukses, serta dapat mewujudkan visi dan misi didalamnya karena setiap orang perlu mendukung upaya mutu. Mutu merupakan perubahan budaya yang menyebabkan organisasi mengubah cara kerjanya, guna meningkatkan produktivitas, Bila mereka tidak mempunyai komitmen maka proses transformasi mutu tidak dapat dimulai. adapun keberhasilan dari menjaga komitmen di MTs Negeri 6 Banjar dapat ditandai dengan:

a. adanya komitmen stakeholders mewujudkan visi dan misi madrasah

MTs Negeri 6 Banjar dalam membangun Komitmen untuk mewujudkan Visi-Misi yaitu dengan mengadakan rapat koordinasi mengingatkan kembali visi dan misi madrasah dan mengevaluasi hal-hal yang belum tercapai dengan tuntas, MTs Negeri 6 Banjar juga memberikan apresiasi reward kepada Guru pembimbing dan pelatih serta siswa yang memenangkan lomba seperti olimpiade atau lomba ekstrakurikuler lainnya, hal ini dilakukan sebagai salah satu cara membentuk komitmen agar para pelatih dan siswa dapat lebih giat dan lebih bersemangat diperlombaan-perlombaan selanjutnya.

Dalam menjaga komitmennya terhadap mutu MTs Negeri 6 Banjar juga mendapatkan penghargaan sebagai juara 2 publikasi berita terbaik di website kanwil kementrian agama provinsi lampung. 
MTs Negeri 6 Banjar dalam menjaga komitmennya pun tidak pernah memulangkan siswa sebelum jam pulang atau karena alasan tidak belajar hal ini juga diungkapkan oleh beberapa Orang Tua Siswa, karena madrasah beranggapan memulangkan siswa lebih awal itu sangat beresiko besar bagi Madrsah, karena dikhawatirkan siswa tidak pulang langsung kerumah masingmasing, jadi disini madrasah harus benar- benar menjaga kepercayaan masyarakat.

b. mematuhi peraturan yang ada didalam madrasah

MTs Negeri 6 Banjar sebelum menetapkan peraturan dan tata tertib yang ada maka pihak Madrasah mensosialisasikan terlebih dahulu peraturan-peraturan tersebut, baik dalam pertemuan dengan Wali Murid, Siwa, maupun Wali kelas, agar tidak terjadi kesalahfahaman. jika peraturan tersebut berlaku bagi Guru dan Staff maka disosialisasikan melalui rapat atau Waka yang bersangkutan.

Adapun bagi Siswa didalam peraturan setiap masalah mempunyai point masing-masing, jika poin anak sudah 100 maka pihak Madrasah memanggil Orang Tua yang bersangkutan untuk diselesaikan bersama-sama, adapun untuk tenaga pendidik jika melakukan kesalahan atau tidak mematuhi peraturan ditegur dan diberikan arahan melalui Waka yang bersangkutan terlebih dahulu dalam hal ini juga MTs Negeri 6 Banjar mempunyai kode etik Guru dan dan kode etik mengajar.

c. memiliki komitmen jangka penjang untuk melakukan perubahan kearah yang lebih baik

MTs Negeri 6 Banjar dalam menjaga komitmennya terhadap mutu dan melakukan perubahan kearah yang lebih baik, maka madrasah sebisa mungkin memberikan program-program yang mendukung proses pembelajaran dan dapat menunjang siwa ketika berada dijenjang yang lebih tinggi, tidak hanya itu program-program tersebut juga diharapakan dapat berguna ketika siswa berada dilingkungan masyarakat, Begitu juga dengan tenaga pendidik Madrasah memberikan pelatihan-pelatihan yang akan menunjang peruses pembelajaran. Dan yang paling penting madrasah harus tetap update dan mengikuti perkemabangan pendidikan semaksimal mungkin.

Dalam menjaga komitmennya terhadap mutu dan melakukan perubahan kearah yang lebih baik MTs Negeri 6 Banjar pun tidak hanya memberikan program-program yang mendukung proses pembelajaran dan dapat menunjang siwa ketika berada dijenjang yang lebih tinggi, tetapi madrasah pun selalu ikut serta dalam setiap event perlombaan.

Setiap ekstrakurikuler juga terdapat pelatih dan pembimbingnya masing-masing karena proses pembelajaran didalam kelas saja tidak cukup, jadi dengan adanya proses pembelajaran yang baik didalam kelas, didukung oleh program-program madrasah serta adanya ekstrakurikuler yang mendukung Madrasah berharap dapat membentuk siswa yang baik, unggul, dan berguna di Masyarakat.

Berdasarkan pemaparan diatas Implementasi Manajemen Mutu Terpadu Pendidikan dalam hal membangun dan menjaga komitmen di MTs Negeri 6 Banjar sudah berjalan dengan baik dengan selalu diadakannya rapat koordinasi, memberikan reward kepada Guru, pelatih serta siswa yang memenangkan lomba, untuk membangun komitmen madrasah juga membuat peraturan dengan sistem poin bagi siswa, sedangkan untuk tenaga pendidik adanya kode etik guru dan kode etik mengajar, dalam menjaga komitmennya pun madrasah tidak pernah memulangkan siswa sebelum jam pulang, dan madrasah juga ikut serta dalam setiap event perlombaan.

Peneilitian yang dilakukan penulis ini selaras dengan penelitian yang dilakukan oleh Linda Wahyuning membahas tentang Implementasi manajemen mutu terpadu di SMP 11 Ma"arif Bangsalsari, adapun hasil penelitian tersebut menyatakan Dalam segi komitmen yang dibangun SMP 11 Ma"rif memberikan kompensasi agar para karyawan bekerja secara produktif, begitu juga dengan MTs Negeri 6 Banjar dalam hal membangun komitmen stakeholders untuk mewujudkan visi dan misi madrasah MTs Negeri 6 Banjar memberikan apresiasi reward kepada Guru pembimbing dan pelatih serta siswa yang memenangkan lomba seperti olimpiade atau lomba ekstrakurikuler lainnya, hal ini dilakukan sebagai salah satu cara membentuk komitmen agar para pelatih dan siswa dapat lebih giat dan lebih bersemangat diperlombaan- perlombaan selanjutnya.

\subsection{Perbaikan Berkelanjutan}

Suksesnya sebuah lembaga pendidikan harus disertai dengan proses yang sistematis dalam melaksanakan perbaikan secara berkesinambungan. Sekolah mesti melakukan sesuatu yang lebih baik 
untuk esok hari. Kutipan tersebut menjelaskan bahwa perbaikan adalah proses yang tidak boleh berhenti.

Keberhasilan dari perbaikan berkelanjutan di MTs Negeri 6 Banjar dapat ditandai dengan:

a. secara konstan mencari cara untuk memperbaiki setiap proses pendidikan

MTs Negeri 6 Banjar dalam memperbaiki setiap proses pendidikan Madrasah memberikan pelatihan-pelatihan seperti implementasi K13 yang mendatangkan pembicara dari Palembang, pelatihan itupun mengundang beberapa sekolah yang ada di Tanggamus., untuk memperbaiki setiap proses pendidikan Madrasah juga melakukan supervisi kelas yang diadakan setiap 6 bulan sekali, adapun supervisor berasal dari Guru senior yang ada di MTs Negeri 6 Banjar.

b. mengadakan workshop, serta pelatihan-pelatihan

Workshop bagi tenaga pendidik yang ada di MTs Negeri 6 Banjar, sifatnya panggilan dan dilakukan secara bergilir untuk workshop biasanya dilkukan dijakarta atau Palembang. adapun untuk pelatihan, biasanya Madrasah mendatangkan Supervisor dari luar seperti yang sudah dilakukan dalam waktu dekat ini yaitu pelatihan ada berbagai metode pengajaran dan pembuatan RPP, yang dihadiri oleh Guru-guru Madrasah Swasta dilingkungan Talangpadang, Gunung alip dan Gisting.

Berdasarkan pemaparan diatas Implementasi Manajemen Mutu Terpadu Pendidikan dalam hal perbaikan berkelanjutan di MTs Negeri 6 Banjar sudah berjalan dengan baik dengan selalu diadakannya supervisi kelas setiap 6 bulan sekali, serta adanya workshop dan pelatihan-pelatihan.

Peneilitian yang dilakukan penulis ini selaras dengan penelitian yang dilakukan oleh Jam Jami M. Syukri membahas tentang Implementasi manajemen mutu terpadu di SD Negeri 3 Muara Pawan Kabupeten Ketapang Kalimantan Barat. Penelitian tersebut menunjukan bahwa SD Negeri 3 Kecamatan Muara Pawan selalu mengikutsertakan guru dan staff dalam pengembangan serta pelatihan.

\section{KESIMPULAN}

Berdasarkan hasil penelitian dan pembahasan penulis dapat menyimpulkan bahwa:

1. Implementasi manajemen mutu terpadu fokus pada pelanggan di MTs Negeri 2 Tanggamus sudah berjalan cukup baik dengan selalu diadakannya pertemuan secara berkala dengan guru dan staff, serta orang tua. MTs Negeri 6 Banjar telah ditunjang dengan akreditasi yang baik A, dan didukung dengan program-program unggulan yaitu bilingual class, tahfidz, dan juga cub-club sesuai minat dan bakat siswa, adapun dalam hal sarana dan prasarana MTs Negeri 6 Banjar harus lebih diimbangi dengan jumlah siswa yang ada.

2. Implementasi manajemen mutu terpadu pada keterlibatan total sudah berjalan dengan baik dengan adanya rapat guru bidang study setiap satu bulan sekali, MGMP, dan koordinator UN dibawah bimbingan kepala sekolah, serta dibinanya Kerjasama antara Guru dan siswa diluar jam pelajaran, dan adanya Tupoksi sesuai job description masing-masing,

3. Implementasi manajemen mutu terpadu pada pengukuran sudah berjalan dengan baik dengan mempunyai struktur organisasi yang mengandung kontrol, Kepala madrasah pun selalu mengontrol jalannya pembelajaran, dan adanya rapat evaluasi, Evaluasi secara berkala juga dilakukan dalam bentuk supervisi.

4. Implementasi manajemen mutu terpadu pada membangun dan menjaga komitmen sudah berjalan dengan baik dengan selalu diadakannya rapat koordinasi, memberikan reward kepada Guru, pelatih serta siswa yang memenangkan lomba, untuk membangun komitmen madrasah juga membuat peraturan dengan sistem poin bagi siswa, sedangkan untuk tenaga pendidik adanya kode etik guru dan kode etik mengajar, dalam menjaga komitmennya pun madrasah tidak pernah memulangkan siswa sebelum jam pulang, dan madrasah juga ikut serta dalam setiap event perlombaan.

5. Implementasi manajemen mutu terpadu pada perbaikan berkelanjutan juga sudah berjalan dengan baik dengan selalu diadakannya supervisi kelas setiap 6 bulan sekali, serta adanya workshop dan pelatihan-pelatihan. 


\section{DAFTAR PUSTAKA}

A, fuchan. Pengantar Penelitian Dalam Pendidikan. Yogyakarta: Pustaka Pelajar, 2011.

Akhyar, Yundi. Total Quality Management. Jurnal Potensiavol 13. Edisi 01 Januari- juni 2014. Diakses pada 03 Oktober 2018.

Arcaro, Jerome S. Pendidikan Berbasis Mutu. Yogyakarta : Pustataka Pelajar, 2015.

Arikunto, Suharsimi. Prosedur Penelitian Suatu Pendekatan Praktik. Jakarta: Rineka Cipta, 2013.

Creswell, John. W. penelitian kualitatif dan desain riset. Yogyakarta: pustaka pelajar, 2014.

Dames, Mustafa. Idaaratu Al-Juudah Al-Syaamilah Fii Al-Tarbiyyah Wa Al-Ta'liim. Daaru AL-Ghiida', 2008.

Engkoswara \& Komari, Aan. Administrasi Pendidikan. Bandung: Alfabeta, 2015.

Hadis, Abdul \& Nurhayati. Manajemen Mutu Pendidikan. Bandung: Alfabeta, 2014.

Hanik, Umi. Implementasi Total Quality Management Dalam Peningkatan Kualitas Pendidikan. Semarang: RaSail Media Grup, 2011.

Ilham, R. N., Erlina, K. A. F., Silalahi, A. S., Saputra, J., \& Albra, W. (2019). Investigation of the bitcoin effects on the country revenues via virtual tax transactions for purchasing management. Int. J Sup. Chain. Mgt Vol, 8(6), 737.

Iwad, Muhammad. Idaaratu Al-Juudah Al-Syaamilah Fii Al-Maktabaat. Daral Hamed, 2008

Kanji, Gopal K. Total Quality Management. Chapman and Hall in, 1995.

Mardalis. Metode Penelitian. Jakarta: Bumi Aksara, 2014.

Margono, S. Metodologi Penelitian Pendidikan. Jakarta: PT. Rineka Cipta, 2014.

Moleong, Lexy J. Metodologi Penelitian Kualitatif. Bandung : Remaja Rosdakarya, 2016.

Mulyasa, E. Kurikulum Tingkat Satuan Pendidikan, kemandirian Guru dan Kepala Sekolah . Jakarta : Bumi Aksara, 2013

N, Christian. Handbook of Total Quality Management. New York USA:Springer Science and Business, 1998.

Rogers, Rolf E. Implementation of Total Quality Management. New York London: Routledge, 2013.

Sallis, Edward. Total Quality Management In Education. Yogyakarta: IRCiSoD, 2012.

Sarhan, F. Idaaratu Al-Juudah Al-Syaamilah. El-Sherif Mass, 2011. 
Sudjana, Nana \& Ibrohim. Penelitian Dan Penilaian Pendidikan. Bandung: Sinar Baru, 2012.

ST Maryam, R. A., Sumartono, E., \& Dwi Orbaningsih, R. (2020). GLOBAL FINANCIAL CRISIS MANAGEMENT BY HUMAN RESOURCE MANAGEMENT. Journal of Critical Reviews, 7(1), 287-290.

Sugiyono. Metode Penelitian Pendekatan Kuantitatif Kualitatif dan $R \& D$. Bandung: Alfabeta, 2015.

Syaefudin, ubin S. Perencanaan Pendidikan. Bandung: PT Remaja Rosdakarya.

Syukri, Jam M. "Implementasi Manajemen Mutu Terpadu di SD Negeri 03 Muara Pawan Kabupaten Ketapang”. Tersedia di : http://jurnal.untan.ac.id/ (03 Oktober 2018)

Tjiptono, F. Total Quality Management. Yogyakarta: Andi Offset, 2003.

Total Quality Management The Key to Business Improvement. Springer Science Business Media, 1995.

Usman, Husaini. MANAJEMEN Teori, Praktik, dan Riset Pendidikan. Jakarta: Bumi Aksara, 2014.

UU RI No 20 Th. 2003. Sistem Pendidikan Nasional. Jakarta: Sinar Grafika, 2014.

Wahyuning, Linda "Implementasi Manajemen Mutu Terpadu di SMP 11 Ma'arif Bangsalsari”. Vol 5 No. 01. Maret 2013. Tersedia di : http://ejournal.uinsuska.ac.id (03 Oktober 2018).

Yasmina Alqur'an Terjemah dan Tajwid. Bandung: Sygma Creative Media Corp, 2014.

Yasmina, Era. Et.al. "Implementasi Manajemen Mutu Terpadu Dalam Peningkatan Kinerja Sekolah pada SMK Negeri 1 Banda Aceh" Vol 4. No 2 November 2014. Tersedia di : http://jurnal.unsyiah.ac.id (03 oktober 2018) 